\title{
Re-evaluating the place of urban planning history
}

Article

Accepted Version

Adams, D., Larkham, P. and Pain, K. (2015) Re-evaluating the place of urban planning history. Town Planning Review, 86 (4). pp. 373-379. ISSN 1478-341X doi:

https://doi.org/10.3828/tpr.2015.24 Available at

https://centaur.reading.ac.uk/40471/

It is advisable to refer to the publisher's version if you intend to cite from the work. See Guidance on citing.

To link to this article DOI: http://dx.doi.org/10.3828/tpr.2015.24

Publisher: Liverpool University Press

All outputs in CentAUR are protected by Intellectual Property Rights law, including copyright law. Copyright and IPR is retained by the creators or other copyright holders. Terms and conditions for use of this material are defined in the End User Agreement.

\section{www.reading.ac.uk/centaur}

\section{CentAUR}

Central Archive at the University of Reading

Reading's research outputs online 


\section{Re-evaluating the place of urban planning history}

\section{DAVID ADAMS* PETER LARKHAM and KATHY PAIN}

Viewpoint for Town Planning Review

*Birmingham School of the Built Environment

Birmingham City University,

Curzon Street,

Birmingham, B4 7XG

United Kingdom. Tel. 01213317490

david.adams@bcu.ac.uk 


\section{Durable and progressive planning}

Planning is resilient, or so it would seem: in the relatively recent past, it has survived midtwentieth century intellectual assaults by the likes of Jane Jacobs, and her broad criticism that planners hold "deep disrespect [of the] irrationality or chaos of cities" and misunderstand the "relationship of cities [...] with the rest of nature" (Jacobs, 1961, 579). Despite these and other attacks, British planning during the mid-twentieth century rapidly became consolidated as part of state functioning, elevating the role of the discipline as a powerful, institutionalised force to guide future societal change distinct from its parent professions of engineering and architecture. Despite planning's more recent market-led emphasis, planning theory and practice has maintained its engagement with concerns for society and more recently with sustainable development priorities for environmental protection and climate change mitigation.

Planning theory also recognises the role, function and importance of 'world' cities as seats of major political, financial, institutional, cultural and educational power," (Pain, 2015). This is most clearly expressed in the relatively recent invocation of 'spatial planning' - a focus on large-scale spatial structures, typically trans-jurisdictional and cross-sectoral in proactive ways that look to shape future social, economic and environmental policy needs (see Hall and Pain, 2006; Allmendinger and Haughton, 2013; Scott et al., 2013). But whilst planning theory recognizes the importance of the routine practices of 'network economic players' such as in the media, finance, logistics and information industries, in shaping cities of the future (for example, Newman and Thornley, 2012), public sector planning - in England, at least - remains focused on producing development plans operating within fixed geographical boundaries.

This territorial focus of statutory planning stands in contrast to the broad acceptance - at least across parts of the social sciences - that capital, goods, ideas and people 'flow' within a myriad of transnational relations which defy planners' efforts to constrain them (Healey and Upton, 2010), leading some commentators to call for a new planning focus on the relational forms of place making (Allmendinger and Haughton, 2013). In spite of seemingly innumerable government attempts to reform land-use planning in England, statutory 
planning remains a forward-looking function of state activity but with a constrained capacity to act beyond local administrative borders (Pain and Harrison, 2012). Whereas strategy for England's economic development has recently been restructured to focus on 'functional economic areas', with the demise of a regional focus, 'spatial' planning is restricted to the local scale. Ideas of the 'Big Society' invoked as part of the UK Conservative-Liberal Democrat Coalition's (2010 - ) ongoing public service reform agenda also emphasise ‘a return to the local scale' through the devolution of power from central government to neighbourhoods, encouraging communities to take an active role in shaping and planning their local areas (for a recent review of these issues, see Williams et al. 2014).

For all of these reasons, we turn to consider the potential value of historic urban perspectives for un-scaling contemporary spatial planning.

\section{Obstacles and opportunities}

For some, planning should be forward-looking and unencumbered by the antecedents of planning's (multiple) histories (Campbell, 2005): This is entirely understandable, especially when different political parties, think-tanks and civil servants continue to view statutory place-based landuse planning practice as having to be 'fit for purpose' to help deliver new housing, infrastructure, energy generation / efficiency and economic growth . There is little sense that the kinds of 'traditional' evidence used by planning historians - such as documentary records or archives - or the concern, with which they explore, are being incorporated into contemporary planning processes, that have, for some, become transfixed by short-termist policymaking (see Scott et al., 2013). This is a point elucidated by Ward et al. (2011, 250): "[I]n Britain, where recent changes in a planning education system very closely geared towards professional needs have tended to marginalise the position of historians who are not also [and primarily] engaged in more core areas of the planning discipline". Recently, planning education (in Britain, at least) has had to respond to demand for shorter, 'intensive' courses; there has been a significant contraction in the planning and development sector post-2008, and an overall reduction in planning students; departmental restructuring has, in some cases, resulted in disruption and fragmentation of course delivery; while the amount of historical course content has been restricted as 
consequence of some of these changes (. And yet, as the planning historian Anthony Sutcliffe $(1981,67)$ argued over thirty years ago, the value of thoroughly engaging with different planning histories is to gain fresh insights from evaluating and questioning the past in ways that we argue could help 'loosen' curricula from current territorial and practical agendas.

Much planning history scholarship has been accused of focusing on the 'great' plans of 'great' past planners - mostly male, middle-class and Western (Larkham, 2011, 7-8) and for producing a (largely) coherent story of linearity and (ostensibly Anglophone) progress (see Ward et al. 2011). And yet, Sandercock's $(1998,2)$ critique of 'modern' planning has also done much to expose the multiplicity of 'other' histories and 'marginalised' voices. Instructive small-scale 'micro-histories'-) continue to emerge in Western and non-Western contexts that are sensitively attuned to different local social and cultural histories, and, in some instances, help to disrupt 'official' narratives (see Ward et al., 2011, 246-48). However, the is also the danger that by over-emphasising the role of localized accounts of 'difference' (along the fragmented lines of sexual, gender, race, socio-economic backgrounds, disability, age, and so on) in place-based planning frameworks also risks losing sight of the fact that 'we' share common ideas about contemporary and future global concerns. For example, somewhat despairingly, Jane Jacobs (2004, 62-3), for example, laments how the increasing professionalization of (Western) further and higher education during the late-twentieth century led to disciplinary disintegration of knowledge, precisely at the point in time when deep 'joined-up' critical thinking is necessary in order to make "corrective, stabilizing changes" to a world threatened by global socio-economic and environmental crises.

Of course, deep engagement with the past can do much to challenge the sense of dislocation that rapid urban, environmental and societal change can bring. And whilst planning has not been immune to this increased specialization (Davoudi and Pendlebury, 2010), there have, been recent valuable academic studies exploring the way in which historical urban planning ideas and policies 'travel' and have an influence on planning practice in Britain and in other geographical contexts (for example, Harris and Moore, 2013; Cook and Ward, 2014). The recent example of English Garden City revival, serves as a 
reminder that key late-nineteenth century 'foundational' planning ideas still hold a significant theoretical and political fascination, and are seen by some as offering tangible localised solutions to contemporary and future social, economic and environmental problems (TCPA, 2014). The 2014 Wolfson Economics Prize - an initiative supported by the 'UK's leading [government] think tank', Policy Exchange (see http://www.policyexchange.org.uk/) - focused on creating a new UK-based Garden City. In response to this competition, the late Sir Peter Hall - well-known for his seminal contributions to planning history (see Phelps and Tewdwr-Jones, 2014) - and a team of cocollaborators, prepared a strong, albeit unsuccessful, submission to the competition. Their entry incorporated the late-nineteenth century 'social-city' principles of Ebenezer Howard's Garden City, with the more contemporary thinking on sustainable low-carbon forms of development being pursued in Freiburg, Germany.

But one obvious danger here is that such thinking arguably leads to seeking refuge in the past and the evocation of an idealised world of anti-urban, pre-industrial / pre-modern village life. Seeking to integrate historic Garden City ideals - i.e. ideas formed before planning became part of state legislation - into a place-based English statutory planning system, is proving to be a particularly thorny issue (for example, Rogers, 2014). There has also been a wide range of innovative 'unofficial' sustainable development initiatives, including grassroots community gardens and allotments, permaculture sites, land-share and 'transition towns' projects, and certain quasi-official institutional frameworks that, in various ways, purport to encourage community cohesion and develop more socially just and / or environmentally sustainable forms of localized urban living (for a review, see Hardman and Larkham, 2014).

In their different ways, these projects are arguably underpinned by late-nineteenth century 'anti-urban' notions that reify 'nature' where a retreat to the local scale can act as a bulwark against the (perceived negative) forces of macro-economic and environmental change, and social disruption (see Tornaghi, 2014). But several decades of research across the social sciences informs us that state boundaries are inevitably punctured by macro-economic and environmental forces; whilst for others, planning - and planners - can also be (sometimes 
unintentional and / or unsuspecting) participants in the public-private 'roll-out' of neoliberal globalization strategies (see Lizieri and Pain, 2014).

Whilst various local government, third sector and 'ecolocalization' actions of community groups carry the very real potential of being 'incubators of resistance'(Williams et al. 2014, 2806), a focus on the local scale has a serious constraint: whilst presenting opportunities for grass-roots resistance to global forces, local initiatives lack a strategic perspective. Future urban growth will be accelerated by major rural to urban migration focusing on vast, expanding mega-city (regions) in both 'developed' and 'emerging' economies (Harrison and Pain, 2012; Pain, 2015). It is therefore debatable as to whether the future urban society can be sustained through the creation of isolated, single-project, approaches that draw their inspiration - directly or indirectly - from historic ideas of urban living.

\section{Valuing planning history}

Accepting the position that the world is increasingly urban, globalized and interconnected, and that state boundaries are subject to countless dynamic virtual and physical flows, one might be tempted to look to the possibilities of multidisciplinary and / or transdisciplinary research which can offer inventive co-operative opportunities to address contemporary and future challenges (see Reed et al., 2014). And, of course, global exchange of planning ideas has also escalated with the rise of international academic conferences and co-authored publications (Healey and Upton, 2010).

Although British planning has sought to embed wider perspectives in theory, education and practice (see Scott et al., 2013), we would also support the view that a renewed emphasis on history in planning education would certainly have a role to play in halting a perception of its increasing professionalization, myopia, short-termism, and lack of criticality (Ward et al., 2011). As Harrison and Pain (2012) point out, there is a need to learn lessons from the past that remain relevant today and, perhaps, into the future, whilst remaining alert to recent signature contributions in ways that can stimulate debate about what present and future urban form is planned and governed. 
Rather than thinking through how to create locally sustainable urban spaces, looking only through a geographically-bounded (state) lens, or by reference to arguably overly romanticized historic notions of community and urban sustainability, one might argue for more exploration of the feasibility of creating global networks of sustainable cities (see Taylor, 2014Such an approach does not seek to diminish the importance of creative community and local grassroots initiatives; nor do we wish to devalue the contribution of public, private and third sector institutions that do much to try to realize imaginative sustainable ambitions. Rather, we seek to stimulate new critical engagement with planning's legacy of thinking that predates the incorporation, and later neoliberalization, of British planning practice (and thereby planning education) in the spaces of the state.

\section{References}

ALLMENDINGER, P. and HAUGHTON, G. (2013), 'The Evolution and Trajectories of Neoliberal Spatial Governance: 'neoliberal' episodes in planning', Planning Practice and Research, 28 (1), 6-26.

CAMPBELL, H. (2005), 'Reflexivity and the planning academic: challenges and responsibilities', Planning Theory and Practice, 6 (4), 235-237.

COOK, I., WARD, S.V. and WARD, K. (2014), 'A springtime journey to the Soviet Union: Postwar planning and policy mobilities through the Iron Curtain', International Journal of Urban and Regional Research, 38 (3), 805-822.

DAVOUDI, S. and PENDLEBURY, J. (2010), 'Centenary paper - The evolution of planning as an academic discipline', Town Planning Review, 81, 6, 613-45.

HALL, P. and PAIN, K. (eds.) (2006), The Polycentric Metropolis: Learning from mega-city regions in Europe, London, Earthscan.

HALL, P. (2014), Cities of Tomorrow: AN Intellectual History of Urban Planning and Design since 1880, Chichester, Wiley Blackwell.

HARDMAN, M. and LARKHAM, P.J. (2014), Informal Urban Agriculture, Switzerland, Springer. HARRIS, A. and MOORE, S. (2013), 'Planning Histories and Practices of Circulating Urban Knowledge', International Journal of Urban and Regional Research, 37, 5, 1499-509.

HARRISON, J. and PAIN, K. (2012), Global Cities, Volume IV: Planning and Governance of Cities in Globalization, London, Routledge, 438. 
HEALEY, P. and UPTON, R. (eds.) (2010), Crossing Borders - International exchange and planning practices, Abingdon, Routledge.

JACOBS, J. (1961), The Death and Life of Great American Cities, New York, Random House.

JACOBS, J. (2004), Dark Age Ahead, New York, Vintage Books.

LARKHAM, P.J. (2011), 'Questioning planning history' (Working Paper Series No. 2), Birmingham, Birmingham City University.

LIZIERI, C, and PAIN, K. (2010), 'International Office Investment in Global Cities: The Production of Financial Space and Systemic Risk', Regional Studies, 48 (3), 2014, 439455.

NEWMAN, P. and THORNLEY, A. (2012), 'Planning for world cities: shifting agendas and differing politics', in B. Derudder, M. Hoyler, P.J. Taylor, and F. Witlox (eds), International Handbook of Globalization and World Cities, Cheltenham, Edward Elgar.

PAIN, K. (2015), 'World Cities', in D. Richardson, D., N. Castree, M.F. Goodchild, A.L. Kobayashi, W. Liu, R. Marston (eds), The International Encyclopedia of Geography: People, the Earth, Environment and Technology: Economic Geography and Regional Development, John Wiley and Sons, Chichester, The Association of American Geographers, in press.

PHELPS, N. and TEWDWR-JONES, M. (2014), 'A Man for All Regions: Peter Hall and Regional Studies', Regional Studies, 1579-86.

POLICY EXCHANGE (2014), 'Wolfson Economics Prize 2014', available from: http://www.policyexchange.org.uk/wolfsonprize (accessed December 2014).

REED, M.S., STRINGER, L.C., FAZEY, I., EVELY, A.C. and KNUIJSEN, J.H.J. (2014), ‘Five principles for the practice of knowledge exchange in environmental management', Journal of Environmental Management, 146, 337-45.

ROGERS, R. (2014), 'Forget about greenfield sites, build in the cities', The Guardian, $15^{\text {th }}$ July, available from: http://www.theguardian.com/commentisfree/2014/jul/15/greenfield-sites-citiescommuter-central-brownfield-sites (accessed December 2014).

SANDERCOCK, L. (ed.) (1998), Making the invisible visible: a multicultural planning history, Berkeley, University of California Press. 
SCOTT, A.J., CARTER, C., REED, M.R., LARKHAM, P., ADAMS, D., MORTON, N., WATERS, R., COLLIER, D., CREAN, C., CURZON, R., FORSTER, R., GIBBS,P., GRAYSON, N., HARDMAN, M., HEARLE, A., JARVIS, D., KENNET, M., LEACH, K., MIDDLETON, M., SCHIESSEL, N., STONYER, B. (2013), 'Disintegrated development at the rural-urban fringe: Re-connecting spatial planning theory and practice', Progress in Planning, 83, $1-52$.

SUTCLIFFE, A.R. (1981), 'Why planning history?', Built Environment, 7, 65-67.

TAYLOR, P.J. (2014), 'A Research Odyssey: from Interlocking Network Model to Extraordinary Cities', Tijdschrift voor Economische en Sociale Geografie, 105, 4, 38797.

TCPA (TOWN AND COUNTRY PLANNING ASSOCIATION) (2014), 'New Towns and Garden Cities - Lessons for Tomorrow. Stage 1: An Introduction to the UK's New Towns and Garden Cities', London, TCPA.

TORNAGHI, C. (2014), 'Critical Geography of Urban Agriculture', Progress in Human Geography, 38, 4, 551-67.

WARD, S.V., FREESTONE, R. and SILVER, C. (2011), 'Centenary paper - The 'new' planning history: Reflections, issues and directions', Town Planning Review, 82, 3, 231-61.

WILLIAMS, A., GOODWIN, M. and CLOKE, P. (2014), 'Neoliberalism, Big Society, and progressive localism'. Environment and Planning A, 46(12), 2798 - 2815. 
